\title{
2 Religious Syncretism: History of the Concept; the Subject of Research
}

\subsection{Theories of Religious Syncretism: State of Research}

The first known use of term "syncretism" 87 appears in Plutarch's Moralia in a reference to the Cretan practice of putting internal differences aside in the face of external threats, a policy termed "syncretism" (chapter De fraterno amore, Moralia $2.490 \mathrm{~b}$ ). It is worth noting that the concept has political connotations from the very beginning: brotherly love is portrayed by Plutarch as a kind of political strategy aimed at maximising the chances of a group's survival. It is not clear whether the term in Plutarch was a pre-existing concept or a new coinage (Shaw, Stewart 1994, p. 3).

The term "syncretism" entered public debate during the Renaissance on a wave of interest in classical writings, particularly Plato and Aristotle, as it came to describe a synthesis of Christianity and classical Greek philosophy seen as an enriching substrate, particularly in the irenic approach of Erasmus of Rotterdam ${ }^{88}$, which aimed at unifying competing schools of Christian thought (cf. Leopold, Jensen 2005, p. 15). This period brought the modern understanding of syncretism as the bringing together of conflicting or incompatible ideas (cf. Rudolph 2005, p. 69).

The irenic approach proved controversial, provoking suspicions and anti-syncretic fears among many conservative theologians ${ }^{89}$. This anti-syncretic sentiment became particularly heightened among German clergy in the 17th-18th centuries as a reaction to the activity of Georg Calixtus, a Lutheran theologian who worked to reconcile the different factions within Christianity and used the term "syncretism" in the sense of mixing and unifying different religions (Rudolph 2005, p. 69). The debates held at the time as part of the so-called "syncretistic controversy" touched not only on elements of doctrine but also on the problem of administering sacraments to members of different Christian denominations (cf. Shaw, Stewart 1994, p. 4). Many Lutheran theologians, such as Johann Konrad Dannhauer ${ }^{90}$ or Abraham Calov, perceived

87 Etymologically related to the Greek term syngkrasis, something unique, peculiar or individual (cf. Shaw, Stewart 1994, p. 3). The current meaning of the term dates back to a 17th-century etymology derived from synkerannumi or mingling of incompatible things (cf. Rudolph 2005, p. 69; Usener, cited in: Leopold, Jensen 2005, p. 14).

88 This approach has been adopted in the modern ecumenical movement. Irenic ideas also influenced Jesuit missionary efforts (e.g. Francis Xavier in Japan or Matteo Ricci in China), which relied on controlled syncretism where Christianity was adapted to local cultural contexts (cf. Leopold, Jensen 2005, p. 16).

89 This was also reflected in the missionary work of Catholic and Protestant churches until the 20th century (cf. Stewart 2005, p. 265).

90 Author of a monograph on the history of syncretism, Mysterium syncretismi detecti, proscripti et symphonismo compensati (1648), which presents syncretism as a synthesis of heterogeneous things, initiated by Eve and the snake in Paradise. 
syncretism as a pernicious muddle threatening to sow confusion, damage religion and lead souls to perdition (cf. Rudolph 2005, p. 69). The term "syncretism" was seen as "contentious term, often taken to imply 'inauthenticity' or 'contamination', the infiltration of a supposedly 'pure' tradition by symbols and meanings seen as belonging to another, incompatible, tradition” (Shaw, Stewart 1994, p. 1). Attempts to fashion such "pure" traditions ${ }^{91}$ are caused by the need to essentialize the group (cf. Leopold, Jensen 2005, p. 3); in other words, they are constructs aimed at producing an idealized homogeneity in the interest of nativist ideology (Leopold, Jensen 2005, p. 21). Pascal Boyer, a cognitive anthropologist, notes the falsification involved in this kind of approach, which ignores the fact that "people do not live in simple cultural environments where an integrated 'cultural scheme'is shared by most members of the group and unambiguously displayed in various episodes of social interaction. More realistically, we must conceive that, at any time, cultural assumptions are available in many different variants. ... People live in cultural environments where constant undirected variation is the rule rather than the exception" (Boyer, cited in: Martin 2005, p. 288).

The next historical stage in the development of the concept occurred in the second half of the 19th century, when scholars of the Hellenistic culture used the term "syncretism" as a common denominator when referring to "disorder" or "confusion" of that culture (cf. Shaw, Stewart 1994, p. 4). In this sense, syncretism was perceived as a strategy of assimilation which the Roman emperors used in their conquests of new territories, and Hellenistic culture itself was seen as a mixture of Oriental and Western influence $^{92}$ (cf. Leopold, Jensen 2005, p. 20). In the evolutionistic anthropology of the time, the term was used to refer to historically and geographically distant societies.

In the 20th century, the concept of syncretism became fashionable in the social sciences, which viewed syncretism as a historical process ${ }^{93}$ characteristic of all religions (including pointedly anti-syncretic ones). Joachim Wach pointed out that every religion contains a degree of syncretism in its prehistory (cited in: Van der Leeuw 2005, p. 98). Karl Rudolph argues that religions cannot develop without syncretism (Rudolph 2005, p. 80).

Syncretism also features in the thought of Gerard van der Leeuw, a representative of the phenomenological approach in anthropology. The term appears in his Phänomenologie der Religion (1933), a book which appeared in English in 1938 as

91 This was significantly influenced by Hegel's philosophy of history, which produced a preference for monolithic cultures in 19th and 20th-century historiography, treating heterogeneous cultures as "survivals" of older monolithic cultures (cf. Leopold, Jensen 2005, p. 21).

92 That was Hegel's understanding of the Hellenistic culture, accepted by many scholars including J.G. Droysen (cf. Leopold, Jensen 2005, p. 20).

93 Meaning a religion's development over time. In this case, syncretism is not a conscious principle organising the religious life of the community (cf. Baird 2005, p. 49). 
Religion in Essence and Manifestation: A Study in Phenomenology ${ }^{94}$. Van der Leeuw uses the concept of syncretism to explain the transition from poly-demonism to polytheism. He devotes an entire chapter to this problem entitled "Dynamik der Religionen. Synkretismus" in which he argues that forms of religious practice are maintained as their meaning changes, a process he termed "transposition" (Verschiebung) ${ }^{95}$. For example, the meaning of the Holy Communion changes in Protestantism (relative to Catholicism) as the practice is preserved.

The term became popular in American anthropology ${ }^{96}$, which took an optimistic view of syncretism in connection with the vision of America as a melting pot (cf. Shaw, Stewart 1994, p. 5). The term became conceptualised in the field of anthropology mostly as a result of Melville J. Herskovits's studies of acculturation processes. Herskovits, who was a student of Franz Boas, perceived syncretism in terms of salvaging cultural meanings, a major shift compared to the notions of confusion and deviation associated with the term in the first half of the 19th century (cf. Shaw, Stewart 1994, p. 6). Herskovits perceived synkretism as a form of cultural reinterpretation ${ }^{97}$ (cf. Herskovits 1956, p. 554) in which "old meanings are ascribed to new elements or by which new values change the cultural significance of old forms" (Herskovits 1956, p. 553). Herskovits emphasized an emphasis on "identification as the syncretic process” (Apter 2005, p. 165). However, Rosalind Shaw and Charles Stewart have objected to Herskovitz's deterministic and teleological vision of cultural contact leading inevitably to acculturation ${ }^{98}$, emphasizing that the dynamic may produce a range of other outcomes, including anti-syncretic attitudes (Shaw, Stewart 1994, p. 6).

Also important to studies of religious syncretism was the theory produced by the circle known as the Religionsgeschichtliche Schule, which placed syncretism at the

94 Gerardus van der Leeuw, Phänomenologie der Religion (1933). Tübingen: J.C.B. Mohr. English edition: Religion in Essence and Manifestation: A Study in Phenomenology (1938). London: Allen \& Unwin.

95 This is similar to M.J. Herskovits's diffusionism, which defines syncretism as a process of selective adaptation, assimilation and absorption of elements from a different culture (cf. Herskovits 1956, p. 540).

96 Until the 1950s, British anthropology perceived syncretism in negative terms, which Ch. Stewart connects with the colonial policies of the British Empire, as opposed to the ideology of the melting pot in the United States. The other countries in North America, Mexico and Canada, do not present themselves as officially a melting pot: Mexico is historically multicultural and in Canada the Multicultural Act of 1971 re-formed that country as an official mosaic.

97 His examples include the way African deities became identified with Catholic saints by populations of African descent in Catholic countries in the Americas (Herskovits 1956, p. 553, p. 557).

98 He saw syncretism as a stage in the process of acculturation whose dynamic he understood in terms of cultural borrowings which, before they create a new structure, are a kind of experiment in a new way of life. His concept of cultural borrowing is enmashed with Franz Boas's model of "pure cultures" (cf. Leopold, Jensen 2005, p. 145). 
heart of the study of religion (cf. Martin 2005, p. 287). Researchers such as Wilhelm Bousset, Hermann Gunkel, Rudolf K. Bultmann, Hans G. Kippenberg and others rejected the normative theological interpretation of syncretism to reimagine it as a phenomenon through which clashing paradigms produce unique religions (Leopold, Jensen 2005, p. 22); in this sense Christianity, for instance, is treated as a synthesis of the Hellenistic and Judaistic paradigms. Writers from this school also drew the distinction between the canonical, clerical and objective form of religion ("religion") on the one hand, and the subjective and popular religious experience ("religiosity") on the other ${ }^{99}$ (cf. Leopold, Jensen 2005, p. 22). The present book is focused squarely on the latter.

Jacques H. Kamstra continued the phenomenological approach to religion. He treated syncretism as an element in the dynamics of religion, "the coexistence of elements foreign to each other within a specific religion, whether or not these elements originate in other religions or for example in social structures" (cited in: Pye 2005, p. 59). He was mostly interested in "syncretism from within", i.e. taking place within a single religion as opposed to contact with other religions or what Pye calls "a kind of alienation within a religion" as certain elements of its structure survive despite having lost their original meaning (cf. Pye 2005, p. 61). Kamstra believed syncretism to be a typical product of humanity as such, rooted in Claude Lévi-Strauss's la pensée sauvage $e^{100}$. In this understanding, syncretism follows changes in social structure caused by alienation within a religion (cf. Rudolph 2005, p. 73). As the old syntheses disintegrate ("syncretism from within"), they are replaced by new ones (assimilation as as "syncretism from without"). Kamstra's concept has been criticised for its ontological treatment of syncretism as the process would logically have to reduce all phenomena to an undifferentiated mass, contrary to observation (cf. Rudolph 2005, p. 74). Extreme forms of syncretism include amalgamation (fusion) and identification; intermediary forms of syncretism include assimilation and symbiosis (cf. Droogers 1989, p. 10). This understanding of syncretism does not yield itself to ethnographic research, which is synchronous in nature, whereas a diachronic approach is necessary to be able to conclude whether we are dealing with amalgamation, identification or reinterpretation within a given community.

Instead, ethnographic research should primarily focus on identifying the emic categories with which the studied group expresses its own experience of religious syncretism and anti-syncretism. In my research, this experience is articulated in narratives about non-coreligionist neighbours and in the group's various explanations and value judgements relating to shared religious and magical practices, such as visiting shared healers or holy places.

99 According to K. Rudolph, this distinction is characteristic of a Christianocentric outlook, and should not be extrapolated to other religions (cf. Rudolph 2005).

100 Levi-Strauss's bricoleur is the ideal "syncretist" type (Leopold, Jensen 2005, p. 96). 
Another important factor (as noted by Kamstra and others) is the distinction between conscious or deliberate syncretism on the one hand, and unconscious or naïve syncretism the other. Deliberate syncretism is intentional and reflexive (Baird 2005, p. 49, 52), naïve syncretism is random, naïve, spontaneous and vegetative (Leopold, Jensen 2005, p. 26, Colpe, cited in: Rudolph 2005, p. 81). To Kamstra, examples include Christianity, modern Buddhism in Burma and Caodaiism (Cao Đài) in Vietnam. Conscious syncretism is found, among others, in messianic, millenarian and mystical movements (such as modern Sufism), Zen Buddhism, Free Masons or Sikhism (cf: Rudolph 2005, p. 74).

Michael Pye ${ }^{101}$, who engaged with the ideas of Kamstra, believes that studying must involve a focus on "the temporary ambiguous coexistence of elements from diverse religious and other contexts within a coherent religious pattern" (Pye 2005, p. 67). Clashing meanings from different contexts may produce one of three cultural solutions: 1) assimilation - when one meaning "extends" to eliminate the other, 2) the emergence of a new religion - a fusion of meanings which forms a new coherent pattern, or 3) dissolution - a "drifting apart of the two meanings" (Pye 2005, p. 66). According to Hendrik Vroom ${ }^{102}$, this kind of coherence becomes possible in a semiotic "space" formed through religious contact, in which beliefs can be reinterpreted and symbolic incompatibility can become compatible (Vroom, cited in: Leopold, Jensen 2005, p. 92). Vroom believes that such reinterpretation is guided by the principle of avoiding incompatibility between beliefs (cf. Vroom 2005, p. 106).

This tendency to avoid incompatibility is supposed to be an intrinsic quality of human logic, however "[a]ccording to cognitive science, the human brain does not always discriminate logically among information that stems from different systems of thought" (Leopold, Jensen 2005, p. 92). Such processes can be better described in terms of the theory of conceptual blending ${ }^{103}$, a system borrowed from linguistics but applicable to culture studies, developed by the cognitivist Gilles Fauconnier and the cognitivist and linguist Mark Turner ${ }^{104}$, who focus on the importance of the imagination and complex unconscious thought processes in the creation of meaning (cf. Fauconnier, Turner 2003, p. 6). Those processes are responsible for the basic skills of the human mind, starting with the law of identity (A is A) or opposition between objects, to conceptual integration, where different concepts become blended to produce new meaning (cf. Fauconnier, Turner 2003, p. 6-7). Fauconnier and Turner

101 M. Pye criticizes J.H. Kamstra for his lack of an analysis of meaning, arguing that ambiguity is a more important category than alienation (cf. Rudolph 2005, p. 75).

$102 \mathrm{H}$. Vroom defines syncretism as "the incorporation of incompatible beliefs from one religion by another" (Vroom 2005, p. 27). Vroom sees religious traditions as more or less fluid configurations of compatible beliefs steeped in "historical and hermeneutical processes" (Vroom 2005, p. 106). This definition is similar to the concept of deep syncretism by A. Posern-Zieliński as described in chapter 1. 103 With syncretism as its symptom (Leopold, Jensen 2005, p. 148).

104 They pursued a research programme in this area in 1992-1993 at the University of California, San Diego. 
argue that this set of cognitive skills, underlying every aspect of human cognition, is responsible for most human achievements, including the origins of language, art, religion or science (cf. Fauconnier, Turner 2003, p. vi, 7).

At present, there is no scholarly unanimity on the concept of syncretism. Instead of a single universal definition there are numerous competing conceptualisations of religious syncretism. However, the fresh crop of new terms relating to processes of religious synthesis including "creolization”, "bricolage”, "amalgamation” (Kraemer 2005, p. 41) or "multiculturalism" (Peter van der Veer 1994, p. 209) has not been able to fully replace "syncretism" as a research concept. Rosalind Shaw and Charles Stewart have suggested that the concept should be retained where it relates to those religious and ritual phenomena which influence each other and combine two different historical traditions (cf. Shaw, Stewart 1994, p. 9-10).

There is a general agreement that the term syncretism describes "any mixture of two or more religions" which are in contact and influence each other (Ringgren 1969, p. 7). In this context, syncretism is seen as one possible reaction to the insecurity provoked by a confrontation of different religious systems: syncretism is what happens between the two systems to abolish the insecurity, eliminate borders and provoke competitive reactions between the systems (Berner, cited in: Rudolph 2005, p. 77).

Arguably, syncretism tries to reduce the cognitive dissonance caused by religious contact (though not all researchers agree that syncretism does in fact remove it). According to Robert D. Baird the term syncretism should be reserved for situations where conflicting and incompatible ideas or practices collide and become preserved to produce a new whole which is not compatible ${ }^{105}$ (Baird 2005, p. 53). In this way of understanding syncretism, the term can only be legitimately used in situations where the product of the synthesis is not "a harmonious entity" (Baird 2005, p. 56).

A similar perspective can be found in the writings of Hendrik Vroom, who sees syncretism as a process through which a religious tradition incorporates incompatible beliefs and practices ${ }^{106}$ into its main concepts (Vroom 2005, p. 26-35). This takes place at the peripheries of religion, in a semiotic space where formally incompatible beliefs become reinterpreted and reconciled to achieve coherence. In order to make that possible, the beliefs and practices of an existing religion are modified to make it possible to adapt the new beliefs (Vroom 1989, p. 27). This kind of reinterpretation is easiest in the case of beliefs and practices which are seen as marginal by the members of a given religion.

The difficulties involved in using the concept of syncretism are caused by the inability to separate subjective definitions from seemingly objective ones ${ }^{107}$

105 "Syncretism ... merely retains the conflicting elements without having successfully reconciled them” (Baird 2005, p. 53).

106 From the viewpoint of logic (Vroom 1989, p. 27).

107 When examined, they turn out to be subjective (Droogers 1989, p. 8). Even more radically, R.M. Hayden argues that only subjective definitions exist, which either favor the syncretic process 
(Droogers 1989, p. 8). Objective definitions confirm that syncretism is a process of religious mixing without imposing value judgements on the phenomenon. Subjective definitions regard the process from the perspective of the religions involved and see it as legitimate or otherwise (Droogers 1989, p. 7).

Syncretism can be understood as a process of religious synthesis (syncretization, “interpenetration"108), its product ("result") ${ }^{109}$ or both $^{110}$ (Droogers 1989, p. 13). Also, the question arises whether a given syncretic process is symmetrical or marked by relations of dominance (Droogers 2005, p. 224)?

Many researchers have pointed out the need to make a distinction between syncretism from below or from above (Marvin Meyer, Rosalind Shaw, Charles Stewart). Syncretism from below is a situation where religious synthesis is initiated by ordinary members of a community, taking place in an unexamined and unreflective way ${ }^{111}$. In this kind of syncretism meanings are created for personal use and exist outside of the context of political or cultural domination (Shaw). Accordingly, this phenomenon can be referred to as "grassroots" syncretism (Shaw, Stewart). Syncretism from above takes place when the elites of a population come up with syncretic strategies for the "benefit" of the group (i.e. for their own purposes). They impose their religious syntheses on others and claim the right to define cultural meanings. However, as Shaw and Stewart rightly point out, syncretism from above and syncretism from below should not be treated as reified types, and not all religious syntheses can be attributed to the upper or lower social strata, not to mention the fact that grassroots syncretism from below need not be unconscious or unexamined (cf. Shaw, Stewart 1994, p. 17-18).

(when formulated by proponents of multiculturalism) or criticise it (when formulated by people believing in the purity and authenticity of the original rituals facing challenges from external influence (Hayden 2002, p. 207).

108 A term used by some researchers interested in studying the process of religious synthesis itself (Droogers 2005, p. 224).

109 According to A. Droogers, this is where the extent of integration or synthesis is evaluated using concepts such as symbiosis, amalgamation, acculturation, metamorphosis, identification or dissolution (Droogers 2005, p. 224).

110 A. Droogers defines this as "religious interpenetration, either taken for granted or subject to debate” (Droogers 2005, p. 226).

111 The same applies to the division between conscious and unconscious syncretism, considered a key distinction by K. Rudolph. As mentioned above, Rudolph describes unconscious syncretism as a naïve, spontaneous, vegetative or popular phenomenon characteristic of national and ethnic religions of the antiquity, whereas conscious syncretism is a reflective endeavour combining religion and ideology (with examples such as manicures or Ryobu-Shinto in Japan (Rudolph 2005, p. 80). According to Rudolph, such classifications, though useful, should only be used for purposes of preliminary analysis as that the distinction between the religiously reflexive elites (clergy, theologians) and ordinary (unreflective) believers is a simplification. "[T]hese latter are not all passive receptors and objects of doctrinal teaching: they also form independent forms of religious tradition" (Rudolph 2005, p. 81). 
According to André Droogers, the cultural meaning of syncretism will depend on the scholarly perspective, which can range from Marxist (Roger Bastide), symbolic, functional ("what syncretism does) to substantial ("what syncretism is") (Droogers 2005, p. 225).

According to the functional definition, coherence and social consensus are seen as a social norm, and the role of syncretism is to overcome ethnic and cultural contradictions to generate a new synthesis which ensures social coherence. This approach primarily emphasizes the social role of syncretism (Droogers 1989, p. 14).

In the Marxist model, conflict is considered the norm, and syncretism is seen as its (potentially repressive) opposite.

The symbolic approach, which is my preferred approach, perceives all the members of analyzed communities as creators of cultural meanings (Droogers 1989, p. 8; 2005, p. 218). In this approach it is not important which of those states is the norm; instead, the emphasis is placed on how people create and negotiate cultural meanings. From this perspective, syncretism is a kind of culture play ${ }^{112}$ in which people engage using symbols, meanings and, above all, metaphors ${ }^{113}$ (Droogers 2005, p. 230). "Metaphors offer a plethora of meanings and can be reinterpreted so that new meanings are continually added" (Droogers 2005, p. 219). According to Droogers, metaphors also play a key role in the syncretic process in that they provide explanations for events happening to believers (such explanations often involve metaphors derived from different sources) (Droogers 2005, p. 226). In this approach, religious syncretism is perceived as a means of transforming symbolic systems. Droogers emphasises that we need to consider the relationship between transformations to religious symbolic systems and relations of power which "produce” new religions (Droogers 1989, p. 8). "Power then refers to the capacity of certain people to control the behavior of others" (Droogers 2005, p. 220) who often "produce and protect the right metaphor” (Droogers 2005, p. 221).

Like Karl Rudolph, André Droogers emphasises the relationship between syncretism and social structure (Droogers 1989, p. 12, 2005, p. 227). In this sense, syncretism involves not only an exchange of elements between religions but also their adaptation to a new structural context, a procedure which often changes their meaning (Droogers 2005, p. 227). The reverse situation is also possible, in which similarities between metaphors, meanings or models may trigger syncretic processes (Droogers 2005, p. 227). These insights are compatible with the analysis of the

112 As well as a power game (Droogers 2005, p. 226).

113 Also metonymies, which belong to a single field (unlike metaphors, which combine two fields). The difference between a metaphor and a metonymy is a matter of perspective. An external observer's metaphor may be a believer's metonymy, partly reflecting the anthropological distinction between the etic and emic perspectives (cf. Droogers 2005, p. 220). A. Droogers uses the example of a believer who says that the Holy Spirit is wind, a comment which can be understood literally (metonymy) but which to an external observer will only be metaphorical (Droogers 2005, p. 220). 
theorists and researchers mentioned previously, such as Michael Pye, Hendrik Vroom or Helmer Ringgren.

My perspective in this book is close to that of Rosalind Shaw and Charles Stewart (who did his research in Greece), in which syncretism is defined as a process of religious synthesis, analysed dialectically with regard to its opposite, anti-syncretism. "Syncretism has presumably always been part of the negotiation of identities and hegemonies in situations such as conquest, trade, migration, religious dissemination and intermarriage" (Shaw, Stewart 1994, p. 19-20). From this perspective, syncretism is perceived as an adaptation strategy of religious communities which share the same area and live side by side. Presented as an adaptation strategy, this understanding of syncretism corroborates the earlier observations that the process is not clear-cut and unambiguous. Shaw and Stewart believe that both syncretism and anti-syncretism may be involved in producing "authenticity" and identity (1994, p. 9). "Syncretism may be (or perhaps only looks like) a form of resistance, because hegemonic practices are never simply absorbed wholesale through passive 'acculturation'; at the very least, their incorporation involves some kind of transformation, some kind of deconstruction and reconstruction which converts them to people's own meanings and projects" (Shaw, Stewart 1994, p. 20). For this reason, it is worth examining the relationship between changes to symbolic systems and power relations. "Power plays an important role in controlling the access to meaning making” (Leopold, Jensen 2005, p. 154). This play/struggle over religious symbols (who owns them and who is entitled to control and transform their symbolic meanings) should be examined in terms of symmetrical and asymmetrical relationships and influences between religions (Droogers 2005, p. 220-221). In order to identify the strategies of religious synthesis, it is necessary to examine such synthesis as being positioned between religious adaptation and religious antagonism (anti-syncretism). Anti-syncretic attitudes are usually conscious and purposeful, aimed at protecting the purity and authenticity of religion through policing its boundaries (Shaw, Stewart 1994, p. 7).

\subsection{Problems in Studying Muslim-Christian Syncretism in Bulgaria and South-Eastern Europe}

The most useful source for studying Muslim-Christian (or Christian-Muslim) syncretism in South-Eastern Europe is Frederick W. Hasluck's classic Christianity and Islam under the Sultans $\left(1929^{114}\right.$, reprinted in 2005) describing the mutual influence of Islam and Christianity in the Ottoman Empire ${ }^{115}$. Although Hasluck does not use the term

114 Published nine years after his death at the age of 42.

115 Hasluck spent most of his life (1899-1916) in Asia Minor. 
syncretism in his work ${ }^{116}$, his rich material containing instances of interreligious practices from the 19th and early 20th centuries can be productively examined in the context of the modern studies of Muslim-Christian syncretism in the Balkans. Hasluck's material can also be compared to modern examples in an attempt to answer whether the mutual influence of Islam and Christianity had actually produced a syncretic religion in the former Ottoman Empire, and whether this process is continuing or waning today.

Reading Hasluck, I realized that some of the claims to be found in modern scholarship concerning the supposedly problem-free nature of 20th-century MuslimChristian syncretism in the Balkans find no confirmation not only in modern field research, but also in Hasluck's historical material ${ }^{117}$. Hasluck's book contains interesting instances of shallow syncretism, but not of deep syncretism. In this sense it is questionable to argue, as some scholars have done, that religious life in the Rhodopes had been syncretic in nature until as recently as the second half of the 20th century (cf. Popov ${ }^{118}$ 1994, p. 116). For instance, Rachko Popov's descriptions of holidays celebrated by Muslims and Christians create the impression that he understands syncretism in practical terms as a coexistence of certain originally pagan beliefs in local Islam and Christianity (Popov 1994, p. 107).

Hasluck's book contains many descriptions of religious and magical practices shared $^{119}$ by Muslims and Christians as well as rituals connected with shared

116 Hasluck's book contains concepts such as “adaptation” or “amalgamation”, which are interpreted as an element in the political strategy of the Bektashis, which was calculated to achieve assimilation rather than syncretism. Bekatshi Order is a Sufi order highly popular in the Ottoman Empire founded in the 13th century by the semi-legendary figure of Haji Bektash Veli, considered as the patron of the janissary corps; because members of the Bektashi order did not observe Shari'ah law and adopted certain pagan and Christian elements into their cult they were considered heretics by Sunni Muslims. Bektashis did not pray in mosques or abstain from alcohol and they had an egalitarian attitude towards women. They played an important role spreading Islam to Albania and north-eastern Bulgaria and Macedonia. In 1826 the order was abolished by the Sultan, and then banned again in 1925 by Atatürk. There has been a Bektashi revival in Turkey (since the 1950s) and Albania (since the 1990s).

117 Taken both from Hasluck's own material and from the work of other scholars and travellers. Disappointingly, in most cases it is not clear how the material was obtained (hearsay or direct observation). Accordingly, Hasluck analyzes the contacts between Muslims and Christians in the Ottoman Empire in terms of symbolic thinking and not actual cultural practices.

118 "It had preserved its syncretic character almost until the middle of the 20th century, expressed particularly clearly through the parallel existence of pagan and official Christian or Muslim elements. Many beliefs with their related ritual practices or fortune-telling magic, such as Gergiovden, Enyovden, Dimirovden, Marta, Eremiya, Poganite dni and Todorova sedmitsa, are pagan in character and provenance” (Popov 1994, p. 116, translated from Bulgarian).

119 Another factor in their development included the tolerant nature of Shi'ah and Sufi schools of Islam which were prepared to adapt Islam to local beliefs, notably the dervishes, the Kizilbash and the Bektashis. Dervishes (Persian: darvish, Turkish: derviş, Arabic: darwish) are literally "those who walk from door to door", mendicant Muslim monks; members of a Sufi Order, who have taken a sheikh or baba, head of a Muslim monastery or teke (Turkish: tekke, Arabic: takiyyah - a monastery 
presence in the same holy place, each group interpreting such behaviors within its own religious paradigm and often engaging in symbolic appropriation, as is the case of Christian holy places becoming adapted to Muslim beliefs (or, less frequently, vice versa), a development which did not always involve actual administrative takeover ${ }^{120}$. Hasluck explains this phenomenon as a "natural desire to associate it [a holy place - M.L.] with the history of their own religion" (Hasluck 2005 , p. 12) and considers it "usurpation" (Hasluck 2005 , p. 54). For instance, Muslims took not only physical control $^{121}$ of Hagia Sophia in Constantinople, but also appropriated the Basilica in symbolic terms by arguing that the place had long been connected with Islam by events such as its sanctification by the prayers of Solomon or the help provided to Justinian's architect by the mystical figure Khidr ${ }^{122}$ (Turkish: Hıdır/Hızır, Arabic: alKhidr). Another story "connected the repairs after the earthquake of A.D. 538 with Mohammed himself. The dome, so ran the story, fell in on the day the Prophet was born, and could not be repaired till Ilyas/Elijah [Bulgarian: Iliya, Turkish: İlyas, local Muslim variant/Arabic: Ilyas], identified with Khidr, appeared to the Greeks and prescribed the use of mortar compounded of sand from Mecca, water from the well Zem-zem, and saliva of the Prophet” (Hasluck 2005, p. 11).

belonging to the Sufi order of the dervishes) as their spiritual guide. Many Christian converts to Islam were dervishes. Dervishes belonged to different orders (Turkish: tarikat, Arabic: tariqah) such as the Mevlevi Order, the Bektashi Order, or the Malamiyya.

120 Mostly by dervishes, who used shallow syncretism to generate interest in Islam among Christians. Takeovers of Orthodox Christian monasteries usually involved conversions of the Christians to Islam (Zhelyazkova 1990, p. 60).

121 According to Hasluck, converting Christian holy sites to Muslim locations happened in one of three ways: “a) Occupation by force”; "b) Gradual and peaceful intrusion,” in which case a formerly Christian holy place gets converted into a Muslim shrine and the Christian saint becomes identified with a Muslim saint (reincarnation) or is deemed to have been a crypto-Muslim, and “c) Re-occupation of an abandoned site” (Hasluck 2005, p. 58-60).

122 Etymologically often interpreted as meaning "the Green One”. The figure of Khidr is not explicitly named in the Qur'an but it is traditionally assumed that he is referred to in Surah 18 (Al-Kahf or the Cave, 18, 59-81). Khidr is believed to have found the fountain of life and become immortal. Khidr met Musa/Moses [Turkish: Musa, Arabic: Musa] and joined him on his travels, surprising his companion with a series of perplexing actions such as damaging the vessel in which they were travelling, killing a boy playing with his mates or restoring a wall in a village where the travellers were not offered accommodation. In time, his perplexing actions are revealed to have been prompted by mercy and forethought. Because of his expertise in mystical knowledge, the figure of Khidr plays an important role in the Muslim esoteric tradition (cf. Dziekan 1997, p. 22). In Islam, Khidr is considered to be one of the "four immortals" alongside 'Isa, Ilyas (Elijah) and Idris (Enoch). In heterodox Islamic beliefs, the figures of Khidr and Ilyas are often identified (Hasluck 2005, p. 319-320) or believed to be friends who meet. Khidr can also be identified with other figures such as Alexander the Great or St. George (Bulgarian: Sveti Georgi) . According to F.W. Hasluck, the the two saints became identified with each other as part of a deliberate proselytising strategy on the part of heterodox Shi'ah sects, including the Bektashis (Hasluck 2005, p. 335). In Ottoman folklore Khidr was primarily "conceived of as a helper ... especially of travellers" (Hasluck 2005, p. 320). 
Hasluck also provides another example of a Christian place "usurped" (appropriated) Bektashi Muslims, namely the teke $e^{123}$ of Domuz Dere near Keşan in Thrace, formerly a monastery of St. George (Hasluck 2005, p. 54). The site was taken over by Bektashis in the 1840s after an epidemic depopulated a neighbouring Christian village (Hasluck 2005, p. 520). It was visited by Muslims and Christians, but "the representatives of the two religions [did] not mix together more than is necessary” (Hasluck 2005, p. 520).

In the Bulgarian context, one example of Christians appropriating a Muslim holy place is the teke of Akyazili Baba ${ }^{124}$ (Turkish: Akyazılı Baba) in the village of Obrochishte near Balchik in today's south-eastern Bulgaria. Demographic changes in the wake of the Crimean War reduced the Muslim presence, and the site became associated with St. Athanasius (Bulgarian: Sveti Atanas), apparently with no historical or archaeological basis ${ }^{125}$ (Hasluck 2005, p. 91).

123 A monastery in to the Sufi order of the dervishes, headed by a $b a b a$. (Turkish: $b a b a$, Arabic: $b a b a$ ) - literally "father", 1) figuratively - an older, respected person, 2) head of a dervish monastery. 124 According to Austro-Hungarian ethnographer and archeologist F. Kanitz the teke was built by Sultan Suleiman II and burned down by the Russian army in 1829. According to Czech historian and Slavist Konstantin J. Jireček, before the Crimean War it was mostly Muslims who used the powers of Akyazili Baba, a saint who specialized in locating lost cattle. After the war, probably as a result of demographic change, local Christians began receiving supernatural assistance from St. Athanasius. People also visited the place to pray for healing, with a practice involving circling the saint's tomb in his slippers to cure fevers (cf. Hasluck 2005, p. 90-91). The name of the Muslim saint may be derived from his native village of Akyazı in Asia Minor or from rakiya, called ak yazll by the Bektashis: the figure may have discovered rakiya or offered it to members of his Bektashi order as a test (Aleksiev 2005, p. 107).

125 After the Balkan wars the site was transferred to the Bulgarian clergy, and a cross was erected on the tomb alongside the Islamic crescent (Hasluck 2005, p. 92). F.W. Hasluck identifies the site as being originally Muslim (Hasluck 2005, p. 92). According to B. Aleksiev, a modern social anthropologist, Akyazili may have become identified with with St. Athanasius as a result of a popular weather saying which associates the feast of the saint with the beginning of summer (Athanasius is here, summer is here, Turkish: Atanas geldi, yaz geldi (Aleksiev 2005, p. 117). Aleksiev points out that the Turkish version of this weather proverb conflates the name of Atanas with the word yaz (through wordplay on Akyazili/yaz), which might explain why this particular Christian saint came to replace the Bektashi figure (cf. Aleksiev 2005, p. 117). 


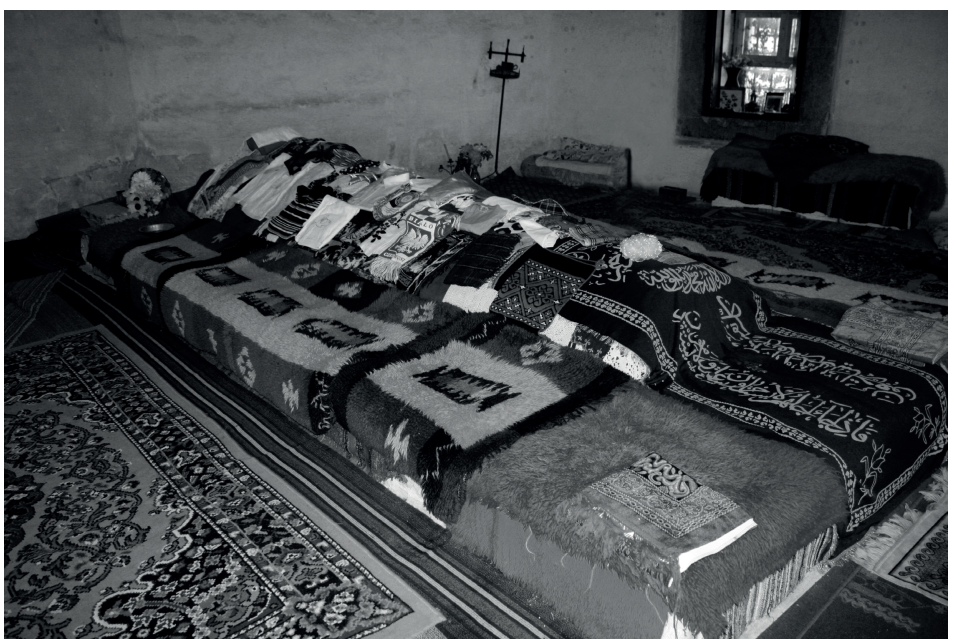

Photograph 2.1: The tyurbe/türbe (tomb) of Akyazili Baba in Obrochishte near Balchik. Photographer: M. Lubanska.

Once appropriated by a new religious group, such sites usually became centers of dual cult ${ }^{126}$, worshipped by Muslims and Christians alike (each group claiming credit for the sites miraculous powers), with the difference between each group's saints being often in name only (Hasluck 2005, p. 81). In such cases, Muslim and Christian saints were identified with each other based on hagiographic parallels. For instance, Khidr was identified with St. George and St. Elijah (Hasluck 2005, p. 570), and Sari Saltik (Turkish: Sarı Saltık or Sar1 Saltuk) ${ }^{127}$ with George as well as St. Nicholas, St. Naum or St. Spyridon. In another example, Muslims and associate Khidr with the unnamed companion of Moses mentioned in the Qur'an, who gained immortality after finding the fountain of life (Hasluck 2005, p. 320). His feast is celebrated on the

126 F.W. Hasluck uses the term "ambiguous cult" (2005, p. 43).

127 Turkish: sar, literally “yellow”, “fair-haired”; a semi-lengendary 13th-century figure of famous miracle-worker. He was believed to have been a member of a mystical Muslim brotherhood, e.g. the Bektashis. Like Khidr, he is identified with various Christian saints including St. George, St. Elijah, St. Simeon or St. Naum. There have been various hypotheses about his actual name (Mehmed, Hizır) and origins; he was even speculated to have been an ascetic and a Christian monk (Aleksiev 2005, p. 19-58; Hasluck 2005, p. 429) and, like Khidr and St. George, a dragon slayer. In areas with mixed religious populations he was often surrounded by a dual cult. He is first mentioned in an account of the travels of Ibn Battuta, a 14th-century traveller. At that time his cult was popular in heterodox Muslim commmunities in the north-western coast of the Black Sea, particularly Dobruja, with his best-known mausoleum in Babadag. His cult also spread to Albania. In some legend he was sent by Haji Bektash to the Balkans as a missionary (Norton 2001, p. 168). 
same day in early spring as St. George’s Day (23 April Old Style, 6 May New Style). In addition to similar chronologies, the two saints are identified with each other because of symbolic parallels, both being known as dragon slayers. Hasluck identifies the probable origins of the identification of Khidr and Elijah in a Talmudic narrative of Rabbi Jochanan's travels with Elijah ${ }^{128}$ to serve as the basis for the later Qur'anic motif of the travel companion of Moses (Hasluck 2005, p. 331-332).

According to a dervish narrative heard by Evlia Efendi in Kaliakra near Varna, another such saint, Sari Saltik, was a disciple of Khoja Ahmed and a companion of Haji Bektash (Turkish: Hacı Bektaş) ${ }^{129}$, sent by Sultan Orhan on a missionary journey to Europe (among other locations, Sari Saltik visited the Crimea, Moscow, and Poland). “At Danzig [today’s Gdańsk - M.L.] he killed the patriarch 'Svity Nikola', and, assuming his robes, in this guise made many converts to Islam” (Hasluck 2005, p. 429). According to another legend, "he ... delivered the kingdom of Dobruja from a seven-headed dragon, to which the two daughters of the King were exposed as victims”. When a monk falsely claimed credit, Sari Saltik proposed an ordeal by fire in which the monk was burned to death, resulting in the king's conversion to Islam (cf. Hasluck 2005, p. 429-430). According to his own wish, parts of Sari Saltik's body were distributed among seven tombs ${ }^{130}$, the seventh of which was located in Kaliakra and was famed for healings of Muslims and Christians (Hasluck 2005, p. 431).

Not infrequently, parallels between saints were emphasized by the dervishes administering a local holy site who hoped to attract a Christian clientele. Hasluck believes that this highlighting of similarities between Christian and Bektashi saints was a tool of deliberate Bektashi propaganda aimed at non-Muslim populations (Hasluck 2005, p. 335), as was the case with the teke of Haji Bektash near Kırşehir in Cappadocia, who became associated with St. Charalambos (cf. Hasluck 2005, p. 84). Haji Bektash's reputation as a saint who averted epidemics may have played a part ${ }^{131}$. Before the teke and its associated saint came to be associated with St. Charalambos, Archbishop Cyril had identified Haji Bektash with St. Eustace who, like Haji Bektash, miraculously exhibited on himself wounds the hunter had inflicted on a stag (Hasluck 2005, p. 85).

128 In Turkish beliefs Ilyas is often conflated with Enoch (Hasluck 2005, p. 333).

129 Haji Bektash gave the name to the heterodox Bektashi Order, probably established in the 13th century in Anatolia. This order was very popular among members of the Janissary corps.

130 Those were located in Moscow, where he was associated with St. Nicholas (Bulgarian: Sv. Nikolay), Danzig, Bohemia, Sweden, Adrianople (with another tomb near Eski Baba east of Adrianople), Baba Dagh in Moldova and Kaliakra (in Southern Dobruja) (cf. Hasluck 2005, p. 430). According to Hasluck, the tomb located near Adrianopole was built on the site of an ancient Orthodox church of St. Nicholas and was frequented by Muslims and Christians (Hasluck 2005, p. 519).

131 St. Charalambos was believed to bring aid in epidemics. Haji Bektash was often identified with St. Charalambos in Macedonia (Hasluck 2005, p. 84, note 6). 
As an alternative explanation, Hasluck mentions the popularity of the belief in the theory of metempsychosis, particularly among the Bektashis; as Hasluck points out "many thoroughly orthodox [Muslim] divines have considered Khidr and Ilyas the same person reincarnated at different periods" (Hasluck 2005, p. 72). In the same way, many Christian saints came to be regarded as "pre-Islamic" Muslims (Hasluck 2005, p. 72) ${ }^{132}$.

Hasluck mentions a double cult relating to a tomb, no longer existing, in the cave of Kaliakra near Varna. Discovered by Bektashis, the tomb was visited both by Christians (as the tomb of St. Nicholas) and by Muslims (as the tomb of Haji Baba) ${ }^{133}$ (Hasluck 2005, p. 51). Before that, the mausoleum was considered by Muslims to be the resting place of Sari Saltik, and Christians believed it to be the tomb of St. Nicholas ${ }^{134}$ (Hasluck 2005, p. 431, 578).

A similar situation described the tomb of St. Naum in Ohrid, who was particularly famed for healing sleepwalkers. The tomb was visited by dervishes, who identified St. Naum with Sari Saltik; the site was venerated not only by dervishes (such as the abbot of the teke in Koritsa (Korçë) ${ }^{135}$, but also by orthodox Sunnis, who believed it originally to have been an Muslim site later appropriated by Christians (Hasluck 2005, p. 70). Another site of dual cult was a tomb in a teke located between Skopje and Kumanovo in Macedonia, believed by Muslims to be the tomb of Karaja Ahmed (Turkish: Karaca Ahmet), and by Christians to be the tomb of St. George (Hasluck 2005, p. 582).

Similarly, Muslims believed that the healing spring in the mosque of Eyüp in Istanbul owed its healing properties to the Arab warrior Abu Ayyub, buried there, whom the visiting Christians associated with Job (Turkish: Eyüp, Arabic: Ayyub) or Samuel (Hasluck 2005, p. 82).

Probably the most interesting example is the teke in Mamasun near Nevşehir, once administered by dervishes. The site used to include both an altar and a picture of St. Mamas ${ }^{136}$ (at the east end of the building), and a mihrab ${ }^{137}$ (in the south wall): "There is no partition between Christian and [Muslim] worshippers, but the latter, while at the prayers, are allowed to turn the picture from them" (Hasluck 2005, p. 576).

In modern Bulgaria, sites of dual Christian-Muslim cult include Mount Kristov or the Church of St. Nicholas (Central Rhodopes) and the monastery of St. George in Hadhzidimovo (Western Rhodopes), as discussed in sections 5.1.2 and 8.1.

132 In Islam, figures such as Adam and Eve or Jesus are recognized as Muslims.

133 Earlier, Sari Saltik, identified with St. Nicholas.

134 F.W. Hasluck speculated that it may have occupied the former location of an old church dedicated to St. Nicholas (Hasluck 2005, p. 434).

135 Hasluck got this information from a Greek abbot (Hasluck 2005, p. 583).

136 Obviously not a canonical Christian saint. His name is probably a back-formation based on the toponym (Hasluck 2005, p. 574).

137 A niche in the wall of a mosque indicating the direction of Mecca, faced by Muslims in prayer. 
On Mount Krastov, both religious groups practice sleeping “for health”, justifying the practice with different legends (Muslim or Christian, respectively) ${ }^{138}$. Muslims and Christians also visit the nearby Yeni-Khan with its tomb of a Muslim saint (Ivanova 2000, p. 108). According to Evgenia Ivanova, pilgrims treat the two sites in utilitarian terms, believing each site to cure different ailments, hence she refers to this phenomenon as “utilitarian” sacrality (Ivanova 2000, p. 125).

Notably, Hasluck pointed out already in the early 20th century that such places of double cult are evidence of religious amalgamation (syncretism) in appearance only; in fact, however, they indicate a process of strategic and selective adaptation, with assimilation as its hidden goal. Hasluck attributes this strategy exclusively to Bektashis: "The concessions of Bektashism to Christianity and of Christianity to Bektashism seem at first sight exactly balanced. Christian churches adopt fictitious Bektashi traditions and receive Bektashi pilgrims: conversely, Bektashi tekes adopt fictitious Christian legends and receive Christian pilgrims. But the apparent equality is only superficial. The ultimate aim of the Bektashi was not to amalgamate Christianity with Bektashism on equal terms, but to absorb Christianity in Bektashism” (Hasluck 2005, p. 586).

In addition to examples of holy sites surrounded by dual cults (which I consider to be instances of superficial syncretism), Hasluck gives examples of negative impacts for the new owners of such holy sites, which can be averted by reintroducing elements of the earlier cult or its trappings. Negative consequences of converting churches into mosques included events such as collapsing mosque domes (e.g. the church in Mersifun, Armenia), minarets being struck by lightning (e.g. the churches of St. John in Rhodos or St. Francis in Galata), earthquakes resulting in partial or total collapse of the building (e.g. the church of St. Sophia in Sofia) or unexplained deaths e.g. the Great Mosque in Aleppo (Hasluck 2005, p. 24). In the case of churches converted to outhouses such as stables, negative effects included unexplained deaths of animal. Robert M. Hayden mentions modern examples, such as the efforts made by the Albanian community in Zocishta to rebuild a local monastery and church after four Albanian men involved in its demolition developed mental health problems (Hayden 2002, p. 213).

With such negative consequences, Frederik W. Hasluck pointed out, holy sites, as it were, "exacted" syncretic behaviours after changing hands. Examples include adding temporary crosses during the construction of mosques (e.g. the mosque in Bulgurlu near Constantinople, erected on the site of an earlier church - Hasluck 2005, p. 31), or the singing of the trisagion (hymn to the Holy Trinity) by the muezzin in addition to the azan (in the Great Mosque in Aleppo - cf. Hasluck 2005, p. 24): the instruction to sing the trisagion was given by Zechariah to spare the life of future

138 For more information, see Atanasov 2000. 
muezzins when two muezzins died in quick succession, and the third prayed to the saint asking to be spared (Hasluck 2005, p. 24) ${ }^{139}$.

One of the most frequently-cited examples of supposed Muslim-Christian syncretism is using the help of the other religion in extreme situations (illness, drought, epidemics). Muslims and Christians did indeed engage in shared religiousmagical practices when faced with threats to both communities. For instance, both groups participated in shared processions in places like Athens, Aleppo or Cairo (Hasluck 2005, p. 64), or, in the Balkans, in the village of Ibrahimovche near Skopje in Macedonia, where Muslims and Christians headed by a local bey ${ }^{140}$ would visit the local Roman altar dedicated to Jupiter where they drank wine, poured libations of wine on the alter and prayed for rain, hoping to placate the local jinni inhabiting the stone (Hasluck 2005, p. 211).

Hasluck noted that both religious groups often believed that healing could be produced by holy water, certain religious icons or relics. Out of the numerous examples Hasluck lists in his books we could mention the Turkish community in Ürgüp (Cappadocia), who in 1908 reacted to an epidemic of cholera among children by asking the Christians to parade the relics of St. John "the Russian" through the Muslim quarter (Hasluck 2005, p. 440, 65): "During the procession the Turkish women threw costly embroidered handkerchiefs on the bier as offerings to the saint who, in answer to their faith, immediately put an end to the epidemic" (Hasluck 2005, p. 65). The inhabitants of Sarajevo ("Greeks, Latins and Turks") believed in a miracle-working picture of the Virgin located in Kurşunlu Cami (Hasluck 2005, p. 66). Near Skopje, there was a healing stone located in a church of the Apostles near the road between Preveza and Yannina: venerated by Christians, the site was also known for healings among Muslims (Hasluck 2005, p. 212). As Hasluck concludes, "throughout Turkey the frequentation of Christian holy places by [Muslims] is not conditional on the antiquity of the sanctuary in question or on any particular form of Christianity being professed in it. Nor is it to be put off by any cult practices theoretically repugnant to [Muslims], such, e.g. as involve the use of the cross or of pictures. Practically any of the religions of Turkey may share the use of a sanctuary administered by another, if this sanctuary has a sufficient reputation for beneficent miracles, among which miracles of healing play a predominant part” (Hasluck 2005, p. 68-69). Apparently, participation in such practices was not treated as a way to salvation but as apotropaic or healing practices. In particular, this applied to situations where the healing did not come from the saint of one's own religion: "In the case of saints, the attraction of healing miracles go far

139 F.W. Hasluck's informant assured him that the tradition of singing the trisagion (a hymn to the Holy Trinity: "Holy God, Holy Strong, Holy Immortal, have mercy on us") was still continued by the local muezzins (Hasluck 2005, p. 24). This is an illustration of enforced shallow religious syncretism. 140 Bey - lord, host, aristocrat, commander. A honorific used to address influential members of the Ottoman military and administrative hierarchy, also applied to rich or influential Muslims generally. 
to overcome all scruples, and Greek no less than Turk admits the idea that, if his own saints fail him, an alien may be invoked"141 (Hasluck 2005, p. 77).

When Christians, including members of clergy, fell ill, they invited emirs and hodzhas to "read [holy texts] over them"; an equivalent practice existed among the Turks: "if a common Turk has a horse sick ... he will have the Alcoran read over it, and, rather than fail, the law of Moses or the Gospel of Christ" (North, cited in: Hasluck 2005, p. 77).

Similar examples can be found in modern research including the English historian and writer Noel Malcolm or professor emeritus of Arabic and Islamic Studies at the University of London, Harry T. Norris. Norris writes that Western travellers noted cases in which infertile Turkish women visited Orthodox churches to drink holy water hoping to be cured of infertility (Heppel, Norris 2001, p. 7). Hasluck explains this by analogy to secular magic involving beliefs in objects and practices including earth taken from graves of saints, oil from holy lamps, candles or incubation (spending a night in a sanctuary); in doing so, Hasluck indicates the importance of sensory practices and the effectiveness of "binding” against illnesses and demons (Hasluck 2005, p. 263-5). The practice of sleeping in holy sites continues to be popular in the Rhodopes. At the same time, both religious groups feared the other religion's magical practices. For instance, the Turkish owner of one of the villages near Üsküp (Skopje) ordered that all stones bearing engraved inscriptions found in his lands should be thrown in the river, "all such being works of the devil and the cursed Giaour" (Hasluck 2005, p. 205).

Noel Malcolm in Crypto-Christianity and Religious Amphibianism... (2001), which focuses mostly on Albania, lists such examples of religious syncretism as visiting the tombs of dervish sheikhs by Christians, use of holy water by Muslims, participating in joint religious observances (Malcolm 2001, p. 94). Malcolm includes religious syncretism as the second form within his typology of religious amphibianism ${ }^{142}$ characterizing the folk religion of the Balkans, where a number of pre-Christian and pre-Slavic practices ("divinatory, medical or apotropaic”) are shared by Muslims and Christians (cf. Malcolm 2001, p. 94). According to Malcolm, the weakest form of amphibianism involves coexistence of religious groups with close social ties (culminating in the coexistence of different religious groups within a single family) ${ }^{143}$. This occasionally led to the "blurring of some religious distinctions" and symptoms of religious syncretism ${ }^{144}$ as the next form of religious amphibianism (Malcolm

141 Where the intercession of a saint from a different religion brought healing, it was followed in some cases by conversion (Hasluck 2005, p. 77).

142 From the Greek amphíbios - "life of both kinds" (usually on land and in water).

143 Malcolm does not identify this situation as an example of crypto-Christianity because it did not involve practising two religions by each member of the family; instead, different members of the family were Christians or Muslims (Malcolm 2001, p. 92).

144 Other examples include the presence of the Muslim members of the family for the ritual of the badnjak (the chopping down of the Christmas tree) or, conversely, the presence of the Catholic part 
2001, p. 93). In mixed families, mutual familiarity with different religious customs was frequently useful in pragmatic purposes contexts, such as being able to pass oneself off as a member of the other religion when travelling or giving Christian family members extra Muslim names to be used to one's advantage when a situation required it ${ }^{145}$ (cf. Malcolm 2001, p. 93).

In this context it should be noted that there is a theory, popular in 19th-century Bulgaria and still enjoying some currency in the modern scholarship of Krasimir Stoilov, Stoyan Raychevski and others, which attributes the syncretic nature of the Islam practised by converts in the Ottoman Empire to their crypto-Christianity. The theory has come under serious criticism; the modern Bulgarian historian Strashimir Dimitrov notes its inaccuracies, which he puts down to incompetence, which has lead many Bulgarian scholars to regard as uniquely Bulgarian many qualities present in Islam from the very beginning. According to Dimitrov, such superficial parallels are then misinterpreted as being quintessentially Christian, leading to the hasty conclusion that Bulgarian-speaking Muslims are in fact Bulgarian converts and crypto-Christians (cf. Dimitrov 2002, p. 14).

At the same time, many scholars, myself included, agree with Noel Malcolm's observation that crypto-Christianity and religious syncretism are completely distinct phenomena, even if the latter made life easier for crypto-Christians (Malcolm 2001, p. 95). According to Malcolm, "a Christian who visited the tyurbe of a Muslim holy man to cure an illness was not pretending to be a Muslim; more importantly, a Muslim who had his children baptised may not have had any idea in his head of creating a secret Christian identity for them" (Malcolm 2001, p. 95-6).

The last form of amphibianism proposed by Malcolm is "theological equivalentism" ${ }^{146}$, in which a community treats Islam and Christianity as alternative ways to salvation (Malcolm 2001, p. 96), embodied in the belief that everyone can be saved in his or her own religion. Malcolm mentions Muslim proselytisers who tactically insisted (on theologically equivalentist grounds) that the opposition between Christianity and Islam was negligible ${ }^{147}$ in order to encourage conversion to Islam (Malcolm 2001, p. 96). This type of religious amphibianism is distinct from cryptoChristianity, which logically would have been "based on the idea that the two faiths were not really equivalent at all, but radically opposed, and that one of them (the secretly held Christian faith) gave salvation, while the other did not” (Malcolm 2001, p. 97).

of the family during the Bayram celebrations, as noted by M. Barjaktarović in the first half of the 20th century in Albania (Barjaktarović, cited in: Malcolm 2001, p. 93).

145 Such extra Muslim names were given at birth (Malcolm 2001, p. 93).

146 N. Malcolm writes about Albania and Kosovo.

147 For instance, they insisted that the Gospels taught the principles of Islam (Malcolm 2001, p. 97). 
Based $^{148}$ on the work of ethnographers and cultural anthropologists who study the religious life of local Christian-Muslim communities in Bulgaria we might conclude that visiting healers belonging to the other religion (Christian clergy, hodzhas, female healers) or the cult of shared holy sites are studied only as an element of traditional (syncretic) religious life (cf. Georgieva 1995, p. 151-153; Georgieva 2003, p. 18; Zirojević 2003, p. 79). Such practices supposedly prove the syncretic nature of the local religion, defined as a mixture of Christian, Muslim and local traditional pagan beliefs which predate Christianity or Islam. Zirojević believes that one such "syncretic element" in Islam is the cult of saints' tombs, worshipped by Muslims and Christians to seek healing or to avert misfortune (cf. Zirojević 2003, p. 79). The same practices are regarded as religious syncretism by the Bulgarian historian Strashimir Dimitrov (Dimitrov 1987). According to Antonina Zhelyazkova, religious contact between Islam and Christianity in Bulgaria involved "a meeting of minds between representatives of the two faiths at shared holy sites where they got to know and influence each other. Rituals of slaughtered sacrificial animals to saints, which had penetrated both religions ${ }^{149}$, led to grass-roots convergence rather than to confrontations between the purist forms of the two orthodox doctrines” (Zhelyazkova 2001, p. 285). According to Milenko Filipović, the dominating forms of belief in the Balkans are neither Islam nor dogmatic Orthodox Christianity, but rather their "folk" versions of both with strong common pagan elements that provided a basis of shared folk beliefs. All this contributed to a high degree of religious syncretism (Filipović, cited in: Roth 2006, p. 22). Noel Malcolm notes correctly that certain key distinctions can become blurred in "this new, complex, mixed-up, parti-col[o]red world of Ottoman religion, in which everything seems to have been merging into everything else in a sort of warm syncretist soup" (Malcolm 2001, p. 92).

As a result, syncretism appears to be seen as an inseparable quality of Bulgarian or Balkan Islam ${ }^{150}$, but also a kind of vague shorthand which accounts for its unorthodox nature to evade its further examination (Gradeva, Ivanova 1998, p. 11). The factors which helped to produce the unorthodox Islam of the Balkans, with its departures from the official Sunni model, are identified as the local prevalence of more-tolerant Sufi schools of Islam (such as Bektashism), which sought to tolerantly adapt Islam to the local beliefs. Tolerance for local traditions is also characteristic of the Hanafi school of Islam which was predominant during the Ottoman Empire.

148 An earlier version of the following section was originally published in article format in Bulgarian (Lubanska 2009a, p. 63-78).

149 This observation that blood sacrifice became part of Christianity as such is obviously inaccurate, and in this context should only apply to the religious practice of Balkan Christians.

150 "In the Balkans, Islam finds expression in a specific syncretic culture originating on the basis of the Muslim religious complex and strongly influenced by the local Christian culture" (Gradeva, Ivanova 1998, p. 11, translated from Bulgarian). 
The existing literature on this reality mostly identifies such healing practices as examples of syncretism, variously attributed to the non-orthodox beliefs of the Bulgarian Muslims arriving in Bulgaria or the non-orthodox nature of the local folk religion (cf. Georgieva 1995, p. 152). Such religious belief is regarded as pragmatic, only loosely anchored in the religious canon, indifferent to religious difference and unthinkingly open to the adaptation of alien beliefs, with syncretism being perceived solely as a process of religious mimicry. This is an overinterpretation not corroborated even by 19th-century material, as demonstrated by examples from Hasluck's studies.

The idea that syncretism in Bulgarian or Balkan Islam can be perceived as a kind of lack of concern about religious difference contradicts the evident insistence on preserving religious differentiation, as noted by scholars working both among Muslims and Christians in the region (Georgieva 1995, p. 144; Lubanska 2007d, p.193). This presents a misleading vision in which a supposedly syncretic folk religion is contrasted with the implicitly anti-syncretic nature of the two religions in their canonical versions.

The results of this type of thinking can be seen where researchers confuse local syncretism with the analogous products of Islam and Christianity as religions derived from a common root. For instance, Tsvetana Georgieva refers to the belief in the same demonic creatures (often with a local pagan provenance) with the same functions but different names as an example of Islamic-Christian syncretism in Bulgaria (cf.Georgieva 2003, p.17). However, this conclusion does not seem reliable as similarities in Christian and Muslim beliefs are often products of historical development involving numerous mutual borrowings, and therefore may not be connected with specific local traditions. Besides, such parallels may be superficial and apparent, serving to conceal the real differences between members of the two religious groups.

Generally similar beliefs indicate little more than certain shared areas between religions: areas which may or may not provide a point of departure for syncretic attitudes and processes. Such similarities were not shaped locally and should not be used to illustrate the supposedly syncretic nature of local Islam or Christianity. If anything, they may stem from the historical development of the two Abrahamic religions, both in the codified (Hebrew prophets mentioned in the Bible and the Qur'an) and uncodified variants (oral religious narratives about Adam and Eve) which recognize (in common with Judaism) the same patriarch and have a certain body of shared beliefs. Nonetheless, major differences are present in the deep layer; in the case of Islam and Christianity, they originate symbolically from their different versions of genealogical descent, with Muslims being identified as descendants of Isma'il/Ishmael (Bulgarian: Izmail, local Muslim variant: Ismail, Turkish: İsmail), born of the slave woman Hagar (arab. Hajar) ${ }^{151}$, and Jews and Christians as descendants of Isaac, son of Sarah.

151 Hence the term "Hagarians", emphasizing Ishmael's birth from Hagar (Lamoreaux 2000, p. 10). This fictitious genealogy initially referred to the Arabs, which according to one folk etymology meant 
I propose that we should move away from looking at syncretism purely as a characteristic of folk religion which leads to a blurring of religious boundaries, an approach I believe has lost its explanatory power and moves us away from, rather than brings us closer to, the religious relations between Muslims and Christians in the Rhodopes because it skirts questions about this specific process in the local Muslim and Christian communities in the Western Rhodopes. This approach mistakenly suggests that Muslims and Christians are unconcerned about religious difference because they believe in heterodox versions of Islam and Christianity based on us shared body of archaic pagan beliefs predating Christianity or Islam (which, according to some theories, the local population never fully embraced) and forge a kind of pagan Christian-Muslim religion ${ }^{152}$.

Contributing to this mistaken impression are certain simplifications to be found in Bulgarian publications, resulting from a different research perspective. For instance, Tania Boneva's article on the "folk worldview" (naroden svetogled), which focuses on the beliefs of Muslims and Orthodox Christians in the Rhodopes (Eastern, Central and Western) often does not specify which beliefs are characteristic of Muslims, and which of Christians, often referring to both jointly as characteristic of the local population (Boneva 1994, p. 7, 8). At times, this creates the impression that we are dealing with a certain syncretic religion in which all specifically Christian or Muslim elements have been lost or become marginal. At the same time, a certain 19th-century slant seems to be informing the most recent literature by scholars such as Stoil Shishkov, Vasil Dechov, Hristo Popkonstantinov, Stefan Bobchev, and even luminaries such as Michail P. Arnaudov or Hristo Vakarelski (Tsaneva, Popov 1994, p. 5-6). Such material is selected in order to reconstruct a sort of imagined, ideal model of "traditional culture", as evident from the title of the volume Rodopi. Traditsyonna, narodna, duhovna i sotsyalnonormativna kultura ${ }^{153}$ (1994) which contains the article by Boneva and the work of other researchers who openly embrace this perspective (Tsaneva, Popov 1994, p. 5).

Bulgarian researchers highlight the influence of folk Islam and folk Christianity on the peaceful nature of Muslim-Christian coexistence with its positive role as part of a system of good-neighbourly relations. We should mention the book Vrŭzki na sŭvmestimost $i$ nesŭvmestimost mezhdu hristiyani i myusyulmani v Bŭlgaria (1995), and especially the article by Tsvetana Georgieva, "Sŭzhitelstvo kato sistema vŭv vsekidneven zhivot na hristiyanite i myusyulmanite v Bŭlgaria” (1995), in which

\footnotetext{
"people expelled by Sarah similar as the term "Saracens", so called "because Hagar has been sent away from Sarah empty (Sarra-kenê)” (Lamoreaux 2000, p. 10), or “Ishmaelites” - “descended from Ishmael (called Banu Isma'il or "the tribe of Isma“il” in Arabic - M.L.), going back to at least the first century BCE. In time, those terms came to be applied to Muslims in general (cf. Lamoreaux 2000, p. 10-11).

152 More moderate researchers write about two types of religious practice, pagan-Christian and PaganMuslim, where certain pagan elements are present $n$ both religious groups (cf. Popov 1994, p. 116).

153 The Rhodopes. Traditional, Folk, Spiritual and Social-Normative Culture.
} 
Georgieva argues that folk Christianity and folk Islam transplant old demonological beliefs onto new surroundings, mixing them with beliefs and rituals imported from

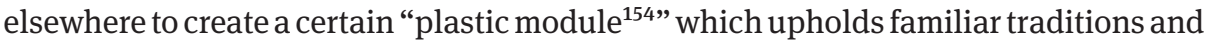
admits innovation in a way that is comprehensible and convenient to Christians and Muslims alike (cf. Georgieva 1995 a, p. 152; 1995 b, p. 165). However, there is a shortage of research into the ways in which the Muslims and Christians themselves interpret the beliefs and practices comprised in the pattern, a project which I undertake in the present book. My research ${ }^{155}$ demonstrates that the syncretic practices are mostly superficial and find no reflection in the religious beliefs of my respondents (Lubanska 2007a, p. 121-135).

The problem of cultural influence between those two religious groups lacks in-depth analysis from Bulgarian sociologists, anthropologists or historians ${ }^{156}$ as published research on the regions inhabited by Muslims and Christians usually presents the two religious cultures in isolation. The rare exception to place the two cultures side by side, especially in the context of the influence of Muslim religious culture on Christian culture, are the publications of Florentina Badalanova Geller (Freie Universität Berlin) studying the ritual of the kurban and its connections with the Abraham/Ibrahim saga among Bulgarian Muslims and Orthodox Christians (2001, 2002a, 2002b, 2003, 2008a, 2008 b).

In this general context my book attempts to read, insofar as this is possible, the cultural meanings of religious syncretism in the context of religious relations between Muslims and Christians within a single local community. I am interested in the process of selection (conscious or otherwise) whereby certain beliefs and practices become incorporated into one's own religion (visiting shared holy sites by Muslims and Christians) or are rejected as threats to one's religious identity (such as Islam's prohibition against praying in front of any representation (i.e. icons) that would distract from a petitioner's focus from Allah).

154 This term seems rather vague: it is not clear what this pattern might comprise and how or by whom it is influenced.

155 It should be borne in mind that my research is not statistical or quantitative in nature, focusing instead on a qualitative analysis of the region of Gotse Delchev. Still, I believe it to be of value to analysts predicting the future of religious relations in the region.

156 A. Zhelyazkova called for such work in the early 1990s, arguing that it would promote a better understanding of the historical development of the Balkan nations (1990, p. 142). When I was working on this book the gap was still unfilled. 